\title{
Effects of captopril in acute and chronic heart failure Correlations with plasma levels of noradrenaline, renin, and aldosterone
}

\author{
G J WENTING, A J MAN IN 'T VELD, A J WOITTIEZ, F BOOMSMA, K LAIRD-MEETER, M L \\ SIMOONS, P G HUGENHOLTZ, M A D H SCHALEKAMP
}

From the Departments of Internal Medicine I and Cardiology, University Hospital Dijkzigt, Erasmus University Rotterdam, Rotterdam, The Netherlands

SUMMARY The angiotensin-converting enzyme inhibitor, captopril, was given to 19 patients with severe heart failure. Seven patients had acute myocardial infarction and the remainder had chronic myocardial damage caused by ischaemia or valvular disease. Cardiac filling pressures were raised in all, the pulmonary capillary "wedge" pressure being $17 \mathrm{mmHg}$ or more. Captopril, $50 \mathrm{mg}$ orally, raised stroke volume and cardiac output, and reduced heart rate, cardiac filling pressures, systemic arterial pressure, and the plasma concentrations of aldosterone and noradrenaline. These changes were attended by clinical improvement. Decrements in cardiac filling pressures, systemic arterial pressure, and total peripheral resistance were positively correlated with pretreatment plasma renin. Long-term treatment with captopril was offered to 14 patients. Four patients with severe coronary disease died suddenly after initial clinical improvement. In nine patients haemodynamic measurements were repeated after three months. The results showed sustained effects on cardiac output and filling pressures but there was no loss of body weight. The haemodynamic effects were at least as good as with previous vasodilators. The fall in systemic arterial pressure, however, was greater with captopril. Captopril may become a valuable adjunct to the treatment of acute and chronic heart failure, but more information about its effect on coronary blood flow is required.

The acute beneficial response to vasodilators in patients with congestive heart failure is well documented. ${ }^{1-4}$ By lowering vascular tone and left ventricular wall tension, these agents improve myocardial contraction and reduce raised filling pressures of the heart. It is now also clear that such a favourable effect is not restricted to drugs that cause vasodilatation because of their direct relaxing effect on vascular smooth muscle. Comparable haemodynamic responses are observed with drugs that reduce sympathetic vascular tone, ${ }^{56}$ act by interruption of the renin-angiotensin-aldosterone cascade,${ }^{78}$ or block serotonergic vascular mechanisms. ${ }^{9}$

Because so many different neurohumoral factors are involved in the circulatory homeostasis of heart failure, however, it is likely that benefits from intervention in one regulatory system are lost by compensatory activation of other systems. In this regard it is significant that, as compared with the abundance of data on the acute benefits of vasodilatory treatment, little is known about its long-term efficacy. ${ }^{1011}$ Experiments with

Accepted for publication 5 October 1982 hydralazine ${ }^{12} 13$ and prazosin ${ }^{1+16}$ suggest that only part of the initial response is maintained. Weight gain, oedema, and increases in the plasma levels of renin, aldosterone, and noradrenaline have been found to accompany tolerance to these drugs. In contrast, the vasodilatory response to inhibitors of angiotensinconverting enzyme is not accompanied by increased sympathetic activity ${ }^{17}$ and aldosterone production ${ }^{18}$ nor by renal sodium and water retention. ${ }^{19}$ Indeed, good results have been obtained with the use of the orally active angiotensin-converting enzyme inhibitor, captopril, even in patients with congestive heart failure refractory to conventional treatment. ${ }^{20-23}$ The role of the renin-angiotensin system in heart failure, however, is not fully understood, ${ }^{2+25}$ and information about the long-term cardiovascular and humoral effects of captopril in heart failure is fragmentary.

With these uncertainties in mind we have studied the acute and long-term effects of captopril in normatensive patients with heart failure and pulmonary congestion. We have tried to correlate these effects with measurements of the plasma levels of noradrenaline, 
renin, and aldosterone. These measurements were considered a rough index of the involvement of the sympathetic nervous system and the renin-angiotensin system in our patients. Two groups of patients were studied. In one group heart failure was an acute condition occurring in the course of myocardial infarction. Plasma noradrenaline was raised in these patients but plasma renin and aldosterone were normal or low in most of them. In a second group heart failure was a chronic treatment-resistant condition, and most patients had high plasma noradrenaline as well as high plasma renin and aldosterone.

\section{Patients and methods}

Nineteen patients with normal blood pressure with heart failure were studied. On the basis of onset and duration of this condition the patients were divided into two groups. Acute pump failure resulting from transmural myocardial infarction was the cause of pulmonary congestion and shortness of breath in the seven patients of group 1 (Table 1). Criteria for inclusion were: mean pulmonary capillary wedge pressure higher than $17 \mathrm{mmHg}$ and systolic arterial pressure between 90 and $150 \mathrm{mmHg}$. Captopril was given to four patients within 12 hours after the onset of myocardial infarction. Digoxin, diuretics, or other vasoactive agents were not used and the interval between the last sedative or pain relieving agent and captopril was at least one hour. Intravenous lignocaine for arrhythmia was necessary in two patients and this was continued during the study. The clinical condition of three patients (Table 1 , cases 5,6, and 7) was such that initial treatment with intravenous dopamine and nitroprusside was indicated. Two to three days after the onset of myocardial infarction, these patients were weaned from intravenous therapy. Recurrence of pulmonary congestion and raised cardiac filling pressures, however, made additional treatment desirable. Captopril was then chosen as an oral substitute for the nitroprusside infusion they had received before. Treatment with dopamine and nitroprusside was stopped at least 12 hours before captopril was given. Group 2 consisted of 12 patients suffering from refractory congestive heart failure for at least two years (Table 2). The aetiology of ventricular failure was secondary to ischaemic heart disease and previous myocardial infarction in seven patients. Three of them had undergone coronary bypass surgery. Persistent poor ventricular function despite aortic or mitral valve

Table 1 Clinical characteristics of patients with acute myocardial infarction

\begin{tabular}{|c|c|c|c|c|c|c|c|c|c|}
\hline \multirow{2}{*}{$\begin{array}{l}\text { Case } \\
\text { No. }\end{array}$} & \multirow{2}{*}{$\begin{array}{l}\text { Age } \\
(y)\end{array}$} & \multirow[t]{2}{*}{ Sex } & \multirow{2}{*}{$\begin{array}{l}\text { Weight } \\
(\boldsymbol{k g})\end{array}$} & \multirow{2}{*}{$\begin{array}{l}\text { Height } \\
(m)\end{array}$} & \multirow{2}{*}{$\begin{array}{l}\text { Localisation of } \\
\text { myocardial infarction }\end{array}$} & \multirow{2}{*}{$\begin{array}{l}\text { CK peak } \\
\text { value }(U / l)\end{array}$} & \multirow{2}{*}{$\begin{array}{l}\text { Time between onset } \\
\text { MI and start } \\
\text { captopril }(h)\end{array}$} & \multicolumn{2}{|c|}{ Therapy $(m g / d)$} \\
\hline & & & & & & & & Digoxin & n Frusemide \\
\hline $\begin{array}{l}1 \\
2 \\
3 \\
4 \\
5 \\
6 \\
7\end{array}$ & $\begin{array}{l}71 \\
55 \\
59 \\
57 \\
45 \\
62 \\
57\end{array}$ & $\begin{array}{l}\mathbf{M} \\
\mathbf{M} \\
\mathbf{M} \\
\mathbf{M} \\
\mathbf{M} \\
\mathbf{M} \\
\mathbf{F}\end{array}$ & $\begin{array}{l}69 \\
76 \\
72 \\
81 \\
60 \\
90 \\
67\end{array}$ & $\begin{array}{l}1 \cdot 75 \\
1 \cdot 74 \\
1 \cdot 64 \\
1 \cdot 72 \\
1 \cdot 78 \\
1 \cdot 76 \\
1 \cdot 69\end{array}$ & $\begin{array}{l}\text { Anterolateral } \\
\text { Anteroseptal } \\
\text { Anterior } \\
\text { Inferior } \\
\text { Posterior } \\
\text { Anteroseptal } \\
\text { Anteroseptal }\end{array}$ & $\begin{array}{r}210 \\
870 \\
1200 \\
345 \\
1600 \\
940 \\
1500\end{array}$ & $\begin{array}{r}4 \\
5 \\
10 \\
12 \\
30 \\
52 \\
72\end{array}$ & $\begin{array}{l}0 \cdot 250 \\
0 \cdot 250 \\
0 \cdot 250\end{array}$ & $\begin{array}{l}240 \\
200 \\
160\end{array}$ \\
\hline
\end{tabular}

Note: $\mathrm{CK}$, serum creatine kinase (normal value 5-30 U/l); MI, myocardial infarction.

Table 2 Clinical characteristics and echocardiographic findings in patients with chronic heart failure

\begin{tabular}{|c|c|c|c|c|c|c|c|c|c|c|c|c|c|c|c|c|c|c|}
\hline \multirow[t]{2}{*}{$\begin{array}{l}\text { Case } \\
\text { No. }\end{array}$} & \multirow[t]{2}{*}{$\begin{array}{l}\text { Age } \\
(y)\end{array}$} & \multirow[t]{2}{*}{ Sex } & \multirow[t]{2}{*}{$\begin{array}{l}\text { Weight } \\
(\mathrm{kg})\end{array}$} & \multirow{2}{*}{$\begin{array}{l}\text { Height } \\
(m)\end{array}$} & \multirow{2}{*}{\multicolumn{2}{|c|}{$\begin{array}{l}\text { Diagnosis and } \\
\text { duration of chronic } \\
\text { heart failure }(y)\end{array}$}} & \multirow[t]{2}{*}{$\begin{array}{l}\text { NYHA } \\
\text { class }\end{array}$} & \multicolumn{4}{|c|}{$\begin{array}{l}\text { Echocardiographic } \\
\text { dimensions (mm) }\end{array}$} & \multicolumn{7}{|c|}{ Therapy $(m g / d)$} \\
\hline & & & & & & & & $L A$ & $L A \mid A o$ & $o L V D$ & $L V S$ & Dig & Fru & Spir & Hyd & Iso & Pra & Nif \\
\hline $\begin{array}{l}8 \\
9 \\
10 \\
11 \\
12 \\
13 \\
14 \\
15 \\
16 \\
17 \\
18 \\
19\end{array}$ & $\begin{array}{l}64 \\
49 \\
63 \\
62 \\
54 \\
67 \\
54 \\
74 \\
59 \\
46 \\
64 \\
46\end{array}$ & $\begin{array}{l}\mathbf{M} \\
\mathbf{F} \\
\mathbf{M} \\
\mathbf{M} \\
\mathbf{M} \\
\mathbf{M} \\
\mathbf{M} \\
\mathbf{F} \\
\mathbf{F} \\
\mathbf{M} \\
\mathbf{F} \\
\mathbf{M}\end{array}$ & $\begin{array}{l}72 \\
72 \\
61 \\
76 \\
67 \\
66 \\
58 \\
60 \\
65 \\
78 \\
73 \\
79\end{array}$ & $\begin{array}{l}1.68 \\
1.63 \\
1.79 \\
1.82 \\
1.75 \\
1.68 \\
1.75 \\
1.69 \\
1.68 \\
1.80 \\
1.66 \\
1.68\end{array}$ & $\begin{array}{l}\text { IHD } \\
\text { IHD } \\
\text { IHD CB } \\
\text { VHD MV } \\
\text { IHD CB } \\
\text { IHD } \\
\text { VHD A+MV } \\
\text { VHD MV } \\
\text { VHD AV } \\
\text { IHD CB } \\
\text { VHD MV } \\
\text { IHD CB }\end{array}$ & $\begin{array}{l}3 \\
2 \\
3 \\
2 \\
2 \\
2 \\
3 \\
6 \\
2 \\
3 \\
5 \\
5\end{array}$ & $\begin{array}{l}\text { IV } \\
\text { IV } \\
\text { IV } \\
\text { III } \\
\text { IV } \\
\text { IV } \\
\text { IV } \\
\text { IV } \\
\text { IV } \\
\text { IV } \\
\text { IV } \\
\text { III }\end{array}$ & $\begin{array}{l}50 \\
52 \\
45 \\
72 \\
60 \\
60 \\
63 \\
65 \\
55 \\
65 \\
70 \\
45\end{array}$ & $\begin{array}{l}1.43 \\
1.63 \\
1.50 \\
1.89 \\
2.00 \\
1.71 \\
1.70 \\
1.86 \\
1.38 \\
2.32 \\
1.89 \\
1.66\end{array}$ & $\begin{array}{r}85 \\
70 \\
78 \\
70 \\
75 \\
100 \\
90 \\
60 \\
50 \\
62 \\
70 \\
73\end{array}$ & $\begin{array}{l}70 \\
55 \\
68 \\
60 \\
60 \\
90 \\
85 \\
45 \\
35 \\
50 \\
60 \\
59\end{array}$ & $\begin{array}{l}0.125 \\
\overline{0.125} \\
0.250 \\
0.250 \\
0.250 \\
0.250 \\
0.125 \\
0.125 \\
0.250 \\
0.250 \\
0.250\end{array}$ & $\begin{array}{rrr}5 & 320 \\
5 & 240 \\
5 & 120 \\
0 & 320 \\
0 & 120 \\
0 & 80 \\
0 & 160 \\
5 & 320 \\
5 & 80 \\
0 & 120 \\
0 & 160 \\
0 & 80\end{array}$ & $\begin{array}{r}150 \\
100 \\
50 \\
-100 \\
100 \\
50 \\
50 \\
50 \\
\overline{100} \\
-\end{array}$ & $\begin{array}{l}200 \\
100 \\
40 \\
200 \\
\overline{-} \\
\overline{200} \\
\overline{-} \\
\overline{200} \\
=\end{array}$ & $\begin{array}{l}80 \\
\frac{80}{80} \\
\frac{80}{\overline{80}} \\
\frac{-}{80} \\
\frac{80}{80}\end{array}$ & $\begin{array}{r}16 \\
8\end{array}$ & 40 \\
\hline
\end{tabular}

IHD, ischaemic heart disease; VHD, valvular heart disease; $\mathrm{CB}$, coronary bypass; $\mathrm{MV}$, prosthetic mitral valve; $\mathrm{AV}$, prosthetic aortic valve; echocardiographic dimensions: LA, left atrial dimension (normal $20-40 \mathrm{~mm}$ ); Ao; aortic root diameter (normal $20-40 \mathrm{~mm}$ ); LA/Ao, ratio between left atrial dimension and aortic diameter (normal 1); LVD, left ventricular end-diastolic dimension (normal 30-55 mm); LVS, left ventricular end-systolic dimension (normal value variable); Dig, digoxin; Fru, frusemide; Hyd, hydralazine; Iso, isosorbide nitrate; Pra, prazosin; Nif, nifedipine. 
replacement was the cause of heart failure in five patients. All complained about shortness of breath at rest despite extensive treatment with dietary sodium restriction, digoxin, diuretics, and hydralazineisosorbide dinitrate combinations or prazosin. Captopril was given to this treatment-resistant group 24 to 36 hours after the vasodilators or prazosin had been stopped.

\section{HAEMODYNAMIC EVALUATION}

The patients of group 1 were admitted to the coronary care unit. A Swan-Ganz thermodilution catheter was positioned in the pulmonary artery and a small Teflon cannula was placed into a radial artery. When stable baseline haemodynamic measurements had been obtained, captopril, $50 \mathrm{mg}$, was given by mouth, and its effect was followed for several hours. In the patients of group 2 invasive haemodynamic monitoring was started during the use of previous vasodilators. For this purpose the patients were transferred to the coronary care unit from the general ward where they had been admitted some days before in order to optimise medical and dietary treatment. Vasodilators or prazosin were then stopped and the withdrawal period of at least 24 hours was covered by invasive monitoring. Digoxin and diurectics were continued, but at least six hours was left between administration of these drugs and the start of captopril. With the evaluation of the first dose of captopril the invasive first part of the study was finished. After treatment lasting three months nine patients of group 2 were readmitted to the coronary care unit for invasive monitoring of the long-term effects of captopril.

\section{MEASUREMENTS}

Heart rate (HR), systemic arterial pressure, and pulmonary arterial pressure were continuously monitored. Triplicate cardiac output measurements by the thermodilution technique were performed at frequent intervals and at that time integrated mean values for systemic arterial pressure (MAP), right atrial pressure (RAP), pulmonary arterial pressure, (PAP) and pulmonary capillary "wedge" pressure (PCWP) were also taken. Pressures and cardiac output were measured with the patient in a semisupine position and the transducers were zeroed at midthoracic level. Cardiac output was corrected for body surface area and tabulated as cardiac index (CI). The following variables were derived: total peripheral resistance in $\mathrm{kPa} / \mathrm{s}$ per 1 as $\mathrm{TPR}=(\mathrm{MAP}-\mathrm{RAP}) / \mathrm{CI}$, pulmonary vascular resistance in $\mathrm{kPa} / \mathrm{s}$ per 1 as $\mathrm{PVR}=(\mathrm{PAP}-\mathrm{PCWP}) / \mathrm{CI}$, cardiac work index in $\mathrm{J} / \mathrm{min}$ as $\mathrm{CWI}=(\mathrm{MAP}-\mathrm{PCWP}) \times \mathrm{CI}$, and stroke work index in $\mathrm{J}$ as $\mathrm{SWI}=(\mathrm{MAP}-\mathrm{PCWP}) \times \mathrm{SI}$, where $\mathrm{SI}$ is stroke volume index.
OTHER MEASUREMENTS AND STATISTICS

Estimations of cardiac chamber size were made by means of $\mathrm{M}$-mode echocardiograms obtained with an ECHO-cardioVISOR SE(Organon Technica, The Netherlands) interfaced to a Honeywell LS 6 strip chart recorder. The dimensions of left atrium, aorta, and left ventricle during end-systole and end-diastole were taken with standard positions of the transducer as described previously. ${ }^{26}$ Arterial and mixed venous oxygen saturations were measured by oximetry. The arteriovenous oxygen difference $\left(\mathrm{AV}-\mathrm{O}_{2}\right)$ in $\mathrm{mmol} / \mathrm{l}$ was calculated as $\mathrm{AV}-\mathrm{O}_{2}=\left(\mathrm{A}_{\mathrm{sat}}-\mathrm{PA}_{\mathrm{sat}}\right) \times \mathrm{Hb} \times 1.01$, where $\mathrm{A}_{\mathrm{sat}}$ and $\mathrm{PA}_{\mathrm{sat}}$ are the arterial and pulmonary arterial (mixed venous) oxygen saturations and $\mathrm{Hb}$ is the haemoglobin content in $\mathrm{mmol} / \mathrm{l}$, while 1.01 is the binding capacity in mmol $0_{2}$ of $1 \mathrm{mmol} \mathrm{Hb}$.

Plasma levels of active renin ${ }^{27}$ and aldosterone ${ }^{28}$ were measured by radioimmunoassay. The normal range for renin in our laboratory is 15 to $45 \mu \mathrm{U} / \mathrm{ml}$. For aldosterone it is 100 to $500 \mathrm{pmol} / \mathrm{l}$. A radioenzymatic technique was used for determining plasma noradrenaline ${ }^{29}$ The normal range is 1 to $3 \mathrm{nmol} / \mathrm{l}$. Data are given as mean \pm SEM. Plasma levels of renin, aldosterone, and noradrenaline were not distributed normally. Mean values and standard errors were therefore calculated after log transformation. Statistical analysis was performed using Student's $t$ test for paired data. Linear regression analysis was used for calculation of correlation coefficients. Statistical significance was accepted at the $95 \%$ confidence level.

\section{Results}

PRE-CAPTOPRIL EVALUATION

Patients with myocardial infarction

Pre-captopril values of arterial pressure were somewhat higher and central pressures were lower than in the patients with chronic heart failure (Tables 3 and 4). Though plasma noradrenaline was raised in all cases, plasma renin and aldosterone were normal in the previously untreated cases (Table 5, cases 1 to 4).

\section{Patients with chronic congestive heart failure}

The severity of heart failure was not only reflected by their symptoms, as expressed according to the New York Heart Association (NYHA) classification ${ }^{30}$ but the advanced stage of cardiac dilatation was also disclosed by echocardiography (Table 2). Both left atrium and left ventricular cavity dimensions were much increased. Moreover, filling pressures of either side of the heart were high, that is right atrial pressure $14 \pm 2$ $\mathrm{mmHg}$ and pulmonary capillary "wedge" pressure $25 \pm 2 \mathrm{mmHg}$, while cardiac index was low. The mean value for cardiac index of $2 \cdot 6 \pm 0.4 \mathrm{l} / \mathrm{min}$ is probably an overestimation because it does not include three very serious cases, in which no reliable cardiac output 
Table 3 Haemodynamic responses to captopril in patients with acute myocardial infarction

\begin{tabular}{|c|c|c|c|c|c|c|c|c|c|c|c|c|c|c|c|c|c|}
\hline \multirow{3}{*}{$\begin{array}{l}\text { Case } \\
\text { No. }\end{array}$} & \multirow{3}{*}{$\begin{array}{l}\text { Heart } \\
\text { rhythm }\end{array}$} & \multirow{2}{*}{\multicolumn{2}{|c|}{$\begin{array}{l}\text { Heart rate } \\
\text { (beats/min) }\end{array}$}} & \multicolumn{8}{|c|}{ Mean pressure (momHg) } & \multirow{2}{*}{\multicolumn{2}{|c|}{$\begin{array}{l}\text { Cardiac index } \\
(l / \min )\end{array}$}} & \multicolumn{4}{|c|}{ Resistance ( $k P a / s$ per $l$ ) } \\
\hline & & & & \multicolumn{2}{|c|}{ Arerial } & \multicolumn{2}{|c|}{ Right atrial } & \multicolumn{2}{|c|}{ Pubm. artery } & \multicolumn{2}{|c|}{$\begin{array}{l}\text { Pubn. cap. } \\
\text { "wedge" }\end{array}$} & & & \multicolumn{2}{|c|}{ Systemic } & \multicolumn{2}{|c|}{ Pulmonary } \\
\hline & & Before & After & Before & After & Before & Afier & Before & Afier & Before & Afier & Before & Afier & Before & Afier & Before & After \\
\hline $\begin{array}{l}1 \\
2 \\
3 \\
4 \\
5 \\
5 \\
6 \\
7\end{array}$ & $\begin{array}{l}\text { SR } \\
\text { SR } \\
\text { SR } \\
\text { SR } \\
\text { AF } \\
\text { SR } \\
\text { SR }\end{array}$ & $\begin{array}{r}90 \\
86 \\
91 \\
58 \\
105 \\
94 \\
109\end{array}$ & $\begin{array}{r}86 \\
84 \\
80 \\
56 \\
78 \\
90 \\
102\end{array}$ & $\begin{array}{r}117 \\
95 \\
113 \\
87 \\
79 \\
62 \\
98\end{array}$ & $\begin{array}{r}107 \\
91 \\
93 \\
79 \\
62 \\
50 \\
90\end{array}$ & $\begin{array}{r}9 \\
13 \\
12 \\
9 \\
13 \\
17 \\
5\end{array}$ & $\begin{array}{r}6 \\
8 \\
7 \\
8 \\
8 \\
11 \\
0\end{array}$ & $\begin{array}{l}29 \\
28 \\
31 \\
27 \\
30 \\
38 \\
27\end{array}$ & $\begin{array}{l}19 \\
28 \\
24 \\
26 \\
23 \\
33 \\
17\end{array}$ & $\begin{array}{l}20 \\
19 \\
26 \\
24 \\
27 \\
23 \\
17\end{array}$ & $\begin{array}{l}11 \\
16 \\
16 \\
20 \\
18 \\
16 \\
11\end{array}$ & $\begin{array}{l}2.9 \\
2.1 \\
2.8 \\
2.8 \\
1.7 \\
\frac{2.3}{2.3}\end{array}$ & $\begin{array}{l}3.4 \\
2.2 \\
2.9 \\
3.1 \\
2.4 \\
\frac{2}{2.7}\end{array}$ & $\begin{array}{l}298 \\
312 \\
289 \\
223 \\
311 \\
\overline{324}\end{array}$ & $\begin{array}{l}238 \\
302 \\
237 \\
183 \\
180 \\
\frac{267}{26}\end{array}$ & $\begin{array}{r}25 \\
34 \\
14 \\
9 \\
14 \\
\frac{35}{9}\end{array}$ & $\begin{array}{l}19 \\
44 \\
22 \\
16 \\
\frac{17}{18}\end{array}$ \\
\hline $\begin{array}{l}\text { Mean } \\
\pm \text { SEM } \\
\text { p }\end{array}$ & & $\begin{array}{l}90 \\
6 \\
<0\end{array}$ & $\begin{array}{r}82 \\
5 \\
.05\end{array}$ & $\begin{array}{l}93 \\
? \\
?\end{array}$ & $\begin{array}{r}82 \\
7 \\
0.01\end{array}$ & 11 & & $\begin{array}{l}30 \\
1<0\end{array}$ & $\begin{array}{r}24 \\
2 \\
0.01\end{array}$ & 22 & $\begin{array}{c}15 \\
1 \\
0.001\end{array}$ & $\begin{array}{l}2.4 \\
0.2\end{array}$ & $\begin{array}{c}2 \cdot 8 \\
0 \cdot 2 \\
0.01\end{array}$ & $\begin{array}{l}293 \\
15\end{array}<0$ & $\begin{array}{r}235 \\
19 \\
0.01\end{array}$ & 22 & $\begin{array}{r}23 \\
4 \\
N S\end{array}$ \\
\hline
\end{tabular}

Note: Values presented are those obtained before and 90 minutes after administration of captopril, $50 \mathrm{mg}$. SR, sinus rhythm; AF, atrial fibrillation. $1 \mathrm{kPa} / \mathrm{s}$ per $\mathrm{l} \approx 10$ dyn $\mathrm{cm}^{-5}$.

measurements could be obtained. Systemic arterial pressure was already low before captopril, systolic $114 \pm 4 \mathrm{mmHg}$ and diastolic $62 \pm 3 \mathrm{mmHg}$, and, despite extensive use of digoxin, the mean value for heart rate exceeded 80 beats/min. The plasma levels of renin, aldosterone, and noradrenaline were grossly raised (Table 5). Kidney function was moderately impaired as indicated by a serum creatinine of $133 \pm 14 \mu \mathrm{mol} / \mathrm{l}$; the range was 81 to $253 \mu \mathrm{mol} / \mathrm{l}$, with a value above 100 $\mu \mathrm{mol} / \mathrm{l}$ in eight patients.

\section{ACUTE EFFECTS OF CAPTOPRIL}

\section{Haemodynamics}

Captopril improved resting haemodynamics both in the patients with heart failure caused by acute myocardial infarction (Table 3) and the patients with chronic heart failure (Table 4).
Changes in systemic arterial pressure, heart rate, cardiac output, and filling pressures were not much different for the two groups. Therefore in Fig. 1 to 3 the data of both groups have been pooled. Despite decrements in systolic arterial pressure, from $121 \pm 6$ to $96 \pm 6 \mathrm{mmHg}$, and in diastolic pressure, from $66 \pm 3$ to $52 \pm 4 \mathrm{mmHg}$, heart rate was also lowered by captopril, from $88 \pm 3$ to $80 \pm 3$ beats $/ \mathrm{min}$ ( $\mathrm{p}<0.05$, Fig. 1). These effects became apparent after 15 minutes, while the peak effects occurred between 90 and 105 minutes. In eight patients systolic arterial pressure fell below 90 $\mathrm{mmHg}$ and in four below $75 \mathrm{mmHg}$. The fall in arterial pressure was well tolerated. One patient complained about blurred vision at a time when his systolic arterial pressure was $65 \mathrm{mmHg}$. No hypotensive period, however, was associated with the onset or worsening of angina or electrocardiographic abnormalities. Triple

Table 4 Acute haemodynamic responses to captopril in patients with chronic heart failure

\begin{tabular}{|c|c|c|c|c|c|c|c|c|c|c|c|c|c|c|c|c|c|}
\hline \multirow{4}{*}{$\begin{array}{l}\text { Case } \\
\text { No. }\end{array}$} & \multirow{4}{*}{$\begin{array}{l}\text { Heart } \\
\text { rhythm }\end{array}$} & \multirow{2}{*}{\multicolumn{2}{|c|}{$\begin{array}{l}\text { Heart rate } \\
\text { (beats/min) }\end{array}$}} & \multicolumn{8}{|c|}{ Mean pressure $(\operatorname{man} H g)$} & \multirow{2}{*}{\multicolumn{2}{|c|}{$\begin{array}{l}\text { Cardiac index } \\
(l / m i n)\end{array}$}} & \multicolumn{4}{|c|}{ Resistance ( $k P a / s$ per l) } \\
\hline & & & & \multicolumn{2}{|l|}{ Arterial } & \multicolumn{2}{|c|}{ Right atrial } & \multicolumn{2}{|c|}{ Pulm. artery } & \multirow{2}{*}{\multicolumn{2}{|c|}{$\begin{array}{l}\text { Pulm. cap. } \\
\text { "wedge" }\end{array}$}} & & & \multicolumn{2}{|c|}{ Systemic } & \multicolumn{2}{|c|}{ Pulmonary } \\
\hline & & \multirow{2}{*}{ Before } & \multirow{2}{*}{ Afier } & \multirow{2}{*}{ Before } & \multirow{2}{*}{ After } & \multirow{2}{*}{ Before } & \multirow{2}{*}{ After } & \multirow{2}{*}{ Before } & \multirow{2}{*}{ After } & & & \multirow{2}{*}{ Before } & \multirow{2}{*}{ Afier } & \multirow{2}{*}{ Before } & \multirow{2}{*}{ After } & \multirow{2}{*}{ Before } & \multirow{2}{*}{ After } \\
\hline & & & & & & & & & & Before & After & & & & & & \\
\hline $\begin{array}{r}8 \\
9 \\
10 \\
11 \\
12 \\
13 \\
14 \\
15 \\
16 \\
17 \\
18 \\
19\end{array}$ & $\begin{array}{l}\text { SR } \\
\text { SR } \\
\text { SR } \\
\text { AF } \\
\text { SR } \\
\text { AF } \\
\text { AF } \\
\text { PM } \\
\text { AF } \\
\text { SR } \\
\text { SR } \\
\text { SR }\end{array}$ & $\begin{array}{r}111 \\
88 \\
84 \\
75 \\
99 \\
104 \\
71 \\
74 \\
87 \\
82 \\
77 \\
81\end{array}$ & $\begin{array}{l}89 \\
85 \\
72 \\
76 \\
96 \\
90 \\
65 \\
74 \\
85 \\
81 \\
64 \\
80\end{array}$ & $\begin{array}{l}74 \\
85 \\
72 \\
74 \\
88 \\
83 \\
66 \\
65 \\
66 \\
93 \\
87 \\
70\end{array}$ & $\begin{array}{l}34 \\
65 \\
48 \\
65 \\
66 \\
67 \\
36 \\
30 \\
51 \\
79 \\
71 \\
51\end{array}$ & $\begin{array}{r}12 \\
5 \\
13 \\
10 \\
17 \\
16 \\
12 \\
20 \\
18 \\
27 \\
11 \\
6\end{array}$ & $\begin{array}{r}3 \\
-1 \\
2 \\
8 \\
8 \\
9 \\
5 \\
8 \\
9 \\
25 \\
7 \\
-1\end{array}$ & $\begin{array}{l}50 \\
38 \\
41 \\
29 \\
44 \\
38 \\
26 \\
44 \\
34 \\
45 \\
36 \\
30\end{array}$ & $\begin{array}{l}24 \\
29 \\
25 \\
26 \\
36 \\
30 \\
17 \\
31 \\
20 \\
38 \\
25 \\
16\end{array}$ & $\begin{array}{l}34 \\
23 \\
27 \\
18 \\
30 \\
27 \\
18 \\
24 \\
20 \\
33 \\
21 \\
20\end{array}$ & $\begin{array}{r}10 \\
11 \\
16 \\
13 \\
23 \\
19 \\
9 \\
14 \\
12 \\
28 \\
13 \\
10\end{array}$ & $\begin{array}{l}2.3 \\
1.9 \\
1.3 \\
3.3 \\
1.6 \\
-1.7 \\
2.8 \\
4.7 \\
- \\
-3.6\end{array}$ & $\begin{array}{l}2 \cdot 4 \\
2 \cdot 1 \\
2 \cdot 6 \\
3 \cdot 5 \\
2 \cdot 2 \\
-\overline{2.9} \\
3 \cdot 1 \\
4 \cdot 7 \\
- \\
-3.6\end{array}$ & $\begin{array}{c}216 \\
337 \\
363 \\
156 \\
355 \\
\overline{254} \\
129 \\
82 \\
- \\
\overline{142}\end{array}$ & $\begin{array}{l}103 \\
251 \\
142 \\
130 \\
211 \\
- \\
86 \\
57 \\
72 \\
- \\
\overline{116}\end{array}$ & $\begin{array}{l}56 \\
63 \\
86 \\
27 \\
70 \\
38 \\
57 \\
24 \\
- \\
22\end{array}$ & $\begin{array}{l}47 \\
69 \\
28 \\
30 \\
47 \\
\frac{22}{44} \\
14 \\
- \\
13\end{array}$ \\
\hline $\begin{array}{l}\text { Mean } \\
\pm \text { SEM } \\
p\end{array}$ & & $\begin{array}{r}86 \\
4 \\
\end{array}$ & $\begin{array}{r}80 \\
3 \\
.01\end{array}$ & $\begin{array}{r}77 \\
3 \\
\end{array}<0$ & $\begin{array}{r}55 \\
5 \\
0.001\end{array}$ & $\begin{array}{r}14 \\
2\end{array}$ & $\begin{array}{r}7 \\
2 \\
0.001\end{array}$ & $\begin{array}{r}38 \\
2 \\
\end{array}$ & $\begin{array}{r}26 \\
2 \\
0 \cdot 001\end{array}$ & $\begin{array}{r}25 \\
2\end{array}$ & $\begin{array}{c}15 \\
2 \\
0.001\end{array}$ & $\begin{array}{l}2.6 \\
0.4\end{array}$ & $\begin{array}{r}3.0 \\
0.3 \\
0.05\end{array}$ & $\begin{array}{l}226 \\
36\end{array}$ & $\begin{array}{l}130 \\
21 \\
\cdot 01\end{array}$ & $\begin{array}{r}49 \\
8\end{array}$ & $\begin{array}{r}35 \\
6 \\
0.05\end{array}$ \\
\hline
\end{tabular}

Note: Values presented are those obtained before and 90 minutes after administration of captopril, $50 \mathrm{mg}$. PM, pacemaker rhythm. Other abbreviations as in Table 3. 
Table 5 Hormone levels before captopril

\begin{tabular}{lccc}
\hline $\begin{array}{l}\text { Case } \\
\text { No. }\end{array}$ & $\begin{array}{l}\text { Plasma renin } \\
(\mu U / m) \text { ( ) }\end{array}$ & $\begin{array}{l}\text { Plasma } \\
\text { aldosterone } \\
\text { (pmol/l) }\end{array}$ & $\begin{array}{l}\text { Plasma } \\
\text { noradrenaline } \\
\text { (nmol/l) }\end{array}$ \\
\hline 1 & 6 & 166 & $3 \cdot 3$ \\
2 & 14 & 222 & $7 \cdot 2$ \\
3 & 27 & 332 & $4 \cdot 3$ \\
4 & 9 & 111 & $4 \cdot 5$ \\
5 & 1700 & 9970 & $20 \cdot 1$ \\
6 & 540 & 2270 & $17 \cdot 5$ \\
7 & 990 & -943 & $18 \cdot 3$ \\
8 & 990 & 665 & $3 \cdot 7$ \\
9 & 30 & 10500 & $14 \cdot 6$ \\
10 & 4600 & 860 & $2 \cdot 3$ \\
11 & 88 & 2520 & $13 \cdot 9$ \\
12 & 68 & 1270 & $6 \cdot 5$ \\
13 & 200 & 4700 & $4 \cdot 5$ \\
14 & 1400 & 277 & $2 \cdot 4$ \\
15 & 58 & 1770 & $10 \cdot 2$ \\
16 & 330 & 9690 & $6 \cdot 8$ \\
17 & 140 & 8860 & $9 \cdot 2$ \\
18 & 110 & 1220 & $2 \cdot 7$ \\
19 & 78 & & \\
\hline
\end{tabular}

Note: Plasma noradrenaline, $1 \mathrm{nmol} / 1 \approx 169 \mathrm{ng} / \mathrm{l}$. Plasma aldosterone, $1 \mathrm{pmol} / 1 \approx 360 \mathrm{pg} / 1$.

product, that is the product of systolic arterial pressure, heart rate, and pulmonary capillary "wedge" pressure divided by 1000 , fell from $253 \pm 19$ to $119 \pm 13$

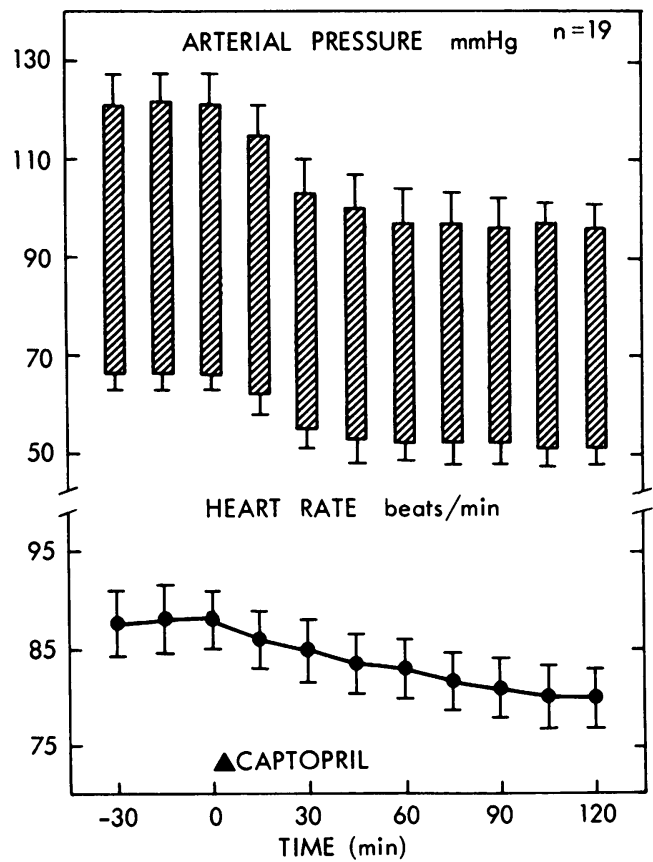

Fig. 1 Responses of systemic arterial pressure and heart rate to a single dose of captopril ( $50 \mathrm{mg})$ in 19 patients with heart failure. The fall in both systolic and diastolic arterial pressure was already significant $(p<0.01) 15$ minutes after captopril. The fall in heart rate became significant $(p<0 \cdot 01)$ after 30 minutes.

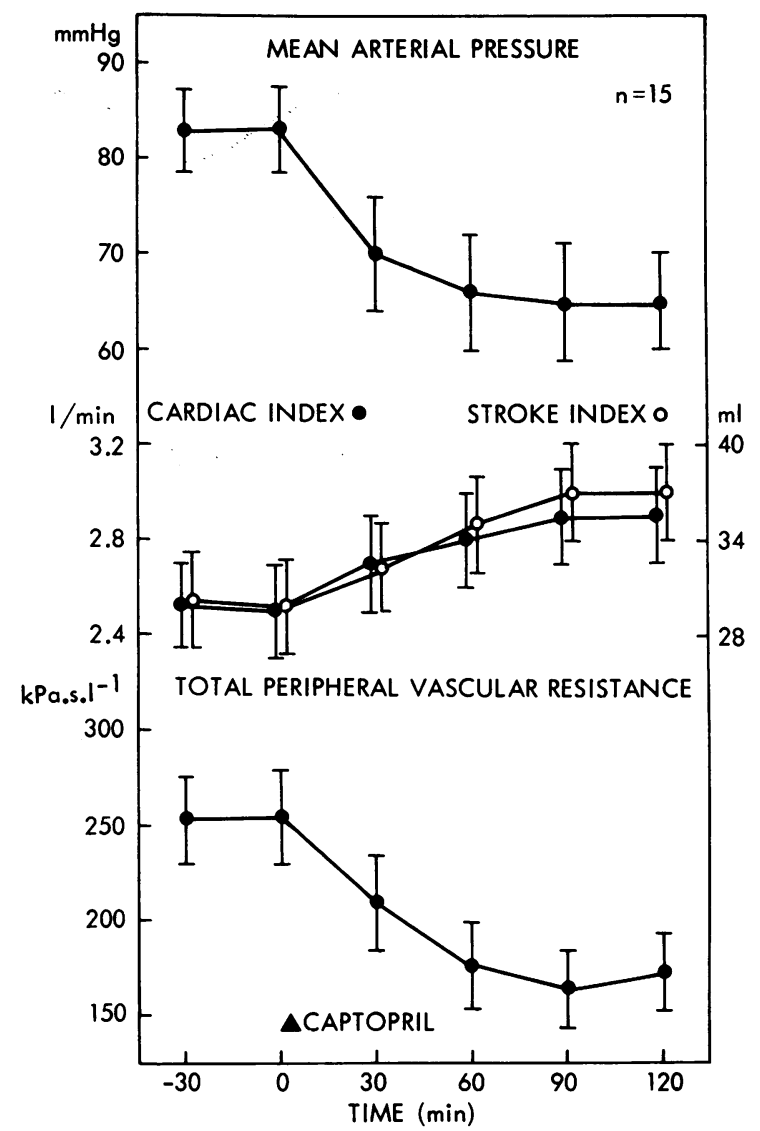

Fig. 2 Effects of captopril (50 mg) on cardiac index, stroke index, mean arterial pressure, and total peripheral resistance. The peak effects were significant at $p<0.01$.

$(\mathrm{p}<0.001)$ presumably leading to a diminished myocardial oxygen demand.

The fall in mean arterial pressure of $25 \pm 4 \%$ was associated with a fall in total peripheral resistance of $30 \pm 5 \%$ (Fig. 2). Cardiac output rose by an increase in stroke volume. This increase in flow was also reflected in the accompanying change in arteriovenous oxygen difference. It fell significantly from $3 \cdot 1 \pm 0.3 \mathrm{mmol} / \mathrm{l}$ before captopril to $2 \cdot 7 \pm 0 \cdot 2 \mathrm{mmol} / \mathrm{l}$ one hour after captopril $(p<0.05)$ and to $2.6 \pm 0.2 \mathrm{mmol} / \mathrm{l}$ two hours after captopril $(p<0.05)$. The amount of work performed by the heart did not change. Cardiac work and stroke work indices before captopril were $20.26 \pm 2.26 \mathrm{~J} / \mathrm{min}$ and $0.24 \pm 0.03 \mathrm{~J}$, respectively, and 90 minutes after captopril they were $19 \cdot 61 \pm 2.58 \mathrm{~J} / \mathrm{min}$ and $0.25 \pm 0.03 \mathrm{~J}$.

Captopril caused parallel decrements in mean pulmonary arterial pressure, pulmonary capillary "wedge" pressure, and right atrial pressure (Fig. 3). 


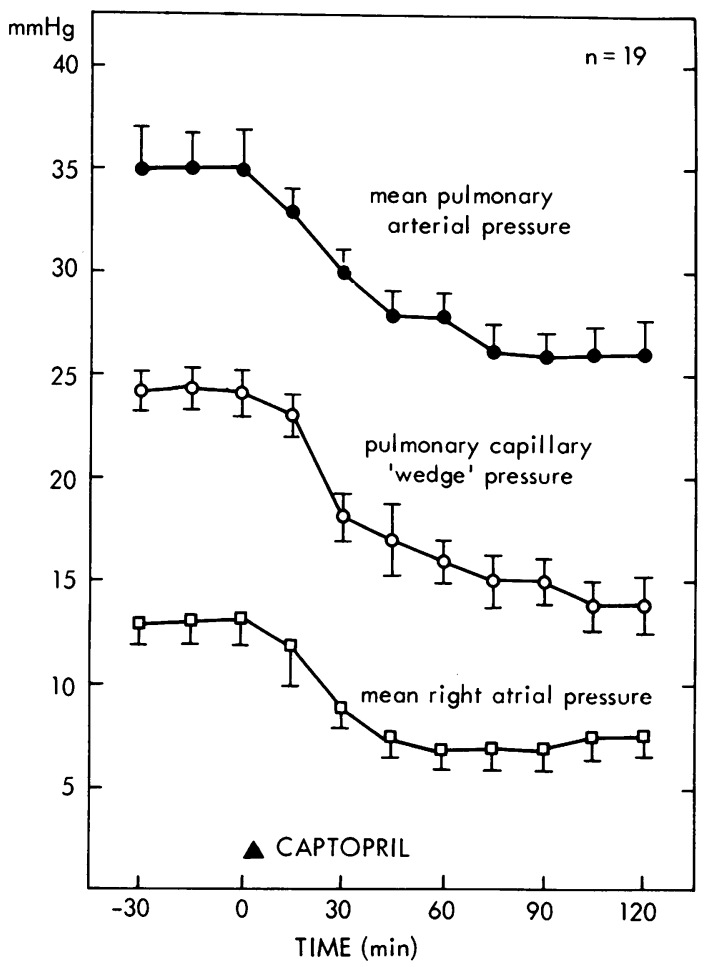

Fig. 3 Captopril (50 mg) caused concurrent decrements in mean pulmonary arterial, pulmonary capillary "wedge", and right atrial pressures. After 30 minutes all changes were significant at $p<0 \cdot 01$.

Pulmonary vascular resistance fell from $38 \pm 6$ to $30 \pm 4$ $\mathrm{kPa} / \mathrm{s}$ per $1(\mathrm{p}<0.05)$. These changes were most pronounced in the chronic heart failure grcup (Table 4).
Plasma renin rose and plasma aldosterone fell after captopril (Fig. 4) as expected. More surprising was the change in plasma noradrenaline; it fell from a mean value of $6.09 \mathrm{nmol} / \mathrm{l}$ before captopril to $5.4 \mathrm{nmol} / \mathrm{l}$ after one hour $(p<0.5)$ and to $4.5 \mathrm{nmol} / \mathrm{l}$ after two hours $(p<0.01)$. The higher the pretreatment value of noradrenaline, the greater was its decrement (Fig. 5).

\section{Interrelations between humoral factors, baseline} haemodynamics, and captopril-induced changes

Pretreatment plasma noradrenaline was directly correlated with pretreatment plasma renin and aldosterone (Table 6). Heart rate before captopril was directly correlated with noradrenaline, suggesting that the high plasma level of noradrenaline indeed reflected an increased sympathetic tone in these patients. Of the flow measurements, pretreatment stroke volume was inversely correlated to plasma noradrenaline but not to renin, whereas cardiac performance, expressed as cardiac work or stroke work, was inversely correlated both with noradrenaline and with renin and also with plasma aldosterone. Total peripheral resistance before captopril, however, was unrelated to the plasma levels of noradrenaline and renin. The decrease in mean and diastolic systemic arterial pressure after captopril but not the decrease in systolic pressure was correlated to pretreatment renin (Fig. 6, Table 7), which suggests that part of the pressure drop was prevented by the observed rise in stroke volume. The decrease in total peripheral resistance after captopril was directly correlated to the pretreatment plasma levels of noradrenaline, renin, and aldosterone.

\section{CLINICAL COURSE}

Patients with myocardial infarction

After the first dose of captopril all patients experienced a reduction in dyspnoea and orthopnoea and in some

Table 6 Correlations between pretreatment haemodynamic variables and pretreatment hormone levels

\begin{tabular}{|c|c|c|c|c|c|c|c|}
\hline \multirow[t]{3}{*}{ Baseline values of } & \multirow[t]{3}{*}{ No. } & \multirow{2}{*}{\multicolumn{2}{|c|}{$\frac{\text { Versus }}{\text { Log plasma renin }}$}} & \multicolumn{4}{|c|}{ baseline values of } \\
\hline & & & & \multicolumn{2}{|c|}{ Log plasma aldosterone } & \multicolumn{2}{|c|}{ Log plasma noradrenaline } \\
\hline & & $r$ & $p$ & $r$ & $p$ & $r$ & $p$ \\
\hline $\begin{array}{l}\text { Arterial pressure systolic } \\
\text { diastolic } \\
\text { mean } \\
\text { Heart rate Cardiac index } \\
\text { Cardiac work index } \\
\text { Stroke index } \\
\text { Stroke work index } \\
\text { Mean right atrial pressure } \\
\text { Mean pulmonary artery pressure } \\
\text { Mean pulmonary capillary "wedge" pressure } \\
\text { Total peripheral vascular resistance } \\
\text { Pulmonary vascular resistance } \\
\text { Log plasma renin } \\
\text { Log plasma aldosterone } \\
\text { Log plasma noradrenaline }\end{array}$ & $\begin{array}{l}18 \\
18 \\
14 \\
14 \\
18 \\
14 \\
18\end{array}$ & $\begin{array}{l}-0.69 \\
-0.42 \\
-0.65 \\
+0.33 \\
-0.31 \\
-0.69 \\
-0.39 \\
-0.73 \\
+0.24 \\
+0.31 \\
+0.28 \\
+0.11 \\
+0.39 \\
+0.78 \\
+0.62\end{array}$ & $\begin{array}{l}<0.001 \\
\text { NS } \\
<0.01 \\
\text { NS } \\
\text { NS } \\
<0 \cdot 01 \\
\text { NS } \\
<0.01 \\
\text { NS } \\
\\
\text { NS } \\
\\
<0.001 \\
<0.01\end{array}$ & $\begin{array}{l}-0.65 \\
-0.10 \\
-0.37 \\
+0.21 \\
-0.37 \\
-0.64 \\
-0.47 \\
-0.72 \\
+0.34 \\
+0.29 \\
+0.27 \\
+0.29 \\
+0.37 \\
= \\
+0.56\end{array}$ & $\begin{array}{c}<0.01 \\
\text { NS } \\
\text { NS } \\
\text { NS } \\
<0.01 \\
\text { NS } \\
<0.01 \\
\text { NS } \\
\text { NS }\end{array}$ & $\begin{array}{l}-0.51 \\
-0.09 \\
-0.19 \\
+0.60 \\
-0.40 \\
-0.49 \\
-0.56 \\
-0.62 \\
+0.30 \\
+0.40 \\
+0.52 \\
+0.43 \\
+0.26 \\
= \\
=\end{array}$ & $\begin{array}{c}<0.05 \\
\text { NS } \\
<0.01 \\
\text { NS } \\
<0.05 \\
<0.05 \\
\text { NS } \\
<0.05 \\
\text { NS }\end{array}$ \\
\hline
\end{tabular}




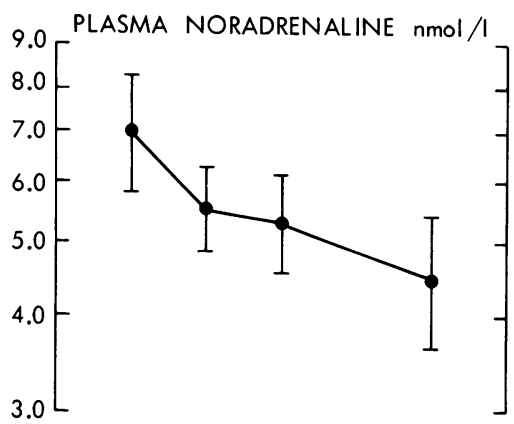

PLASMA RENIN $\mu \mathrm{U} / \mathrm{ml}$

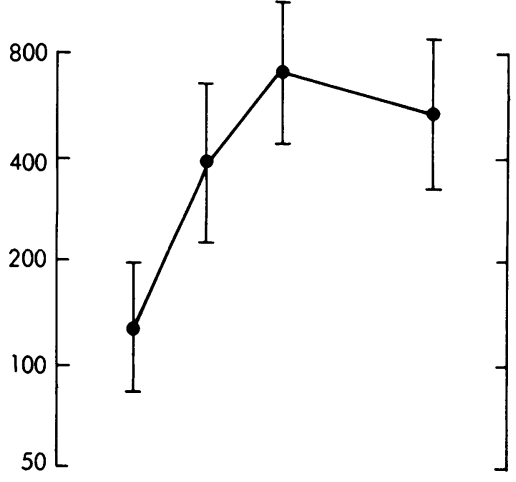

PLASMA ALDOSTERONE $\mathrm{pmol} / \mathrm{I}$
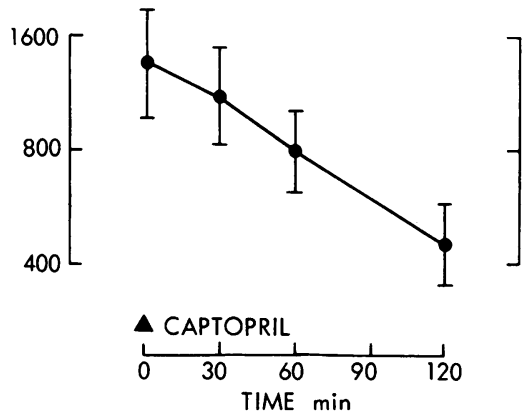

Fig. 4 Neurohumoral responses to captopril $(50 \mathrm{mg})$ in 18 patients with heart failure. Both plasma noradrenaline and aldosterone fell $(p<0.01)$ after 60 minutes, whereas plasma renin rose $(p<0.01)$.

the annoying non-productive cough as a sign of imminent lung oedema disappeared. Signs of heart failure gradually faded away in four patients (cases 1 to 4 ) and cessation of captopril after a few doses was well tolerated. The course of their myocardial infarction was further uneventful. The three patients with more severe pump failure, who had previously been treated with dopamine and nitroprusside, remained on captopril. The dose was gradually increased to $100 \mathrm{mg}$ three times a day, and digoxin and diuretics were con- tinued. One of them, case 5, remained in a critical condition and died after a few days. The two others improved clinically and could be mobilised. Three days after discharge from the hospital, 25 days after the onset of myocardial infarction, case 6 died suddenly. Case 7 was found dead one month after myocardial infarction. At a visit to the outpatient clinic some days before her death the blood pressure was $95 / 75 \mathrm{mmHg}$ while she was taking $300 \mathrm{mg}$ captopril and $160 \mathrm{mg}$ frusemide. At that time she had no complaints and there were no signs of central or peripheral congestion.

\section{Patients with chronic heart failure}

After haemodynamic assessment of the first dose of captopril, which was $\mathbf{5 0} \mathrm{mg}$, long-term treatment was instituted, initially with doses that ranged from 12.5 to $50 \mathrm{mg}$ three times a day, depending on kidney function and on the blood pressure response at the time of the first dose. In case 15 captopril treatment had to be stopped after a few doses because of rapid deterioration of pre-existent mild renal insufficiency, with oliguria. Cases 8 and 14 had supine systolic arterial pressure levels that were persistently below $80 \mathrm{mmHg}$ at a daily dose of $150 \mathrm{mg}$. They complained about blurred vision. In these patients the dose was reduced to $75 \mathrm{mg}$. In the remaining patients the dose of captopril was gradually increased to $300 \mathrm{mg}$ per day, but in three (cases 9,11 , and 17) this led to an increase in serum creatinine, which was reversed by reducing the dose to $75 \mathrm{mg}$.

All patients showed symptomatic improvement which was mainly the result of a lessening of dyspnoea. In two patients a pleural effusion, which was refractory to treatment, disappeared in a few weeks. Captopril treatment, however, did not result in loss of weight; it was $70.4 \pm 2.4 \mathrm{~kg}$ before captopril and $71.5 \pm 2.5 \mathrm{~kg}$ after one week $(n=10)$. Two patients (cases 8 and 10) died in the first month of treatment. Ultimately, nine patients completed a three month treatment period.

Long-term haemodynamic effects of captopril and comparison with previous vasodilatory regimens

In Fig. 7 haemodynamic measurements obtained from repeat right heart catheterisation after three months of captopril treatment were compared with those taken at the start of the study. Our study had been designed in such a way that we were able not only to compare long-term effects of captopril with its acute effects but also with the long-term effects of previous vasodilatory treatment. The significant haemodynamic improvement after the first dose of captopril was maintained in the long run. After three months of captopril, systemic arterial pressure, pulmonary arterial pressure, pulmonary capillary "wedge" pressure, cardiac index, and total peripheral resistance all still differed significantly from values measured shortly before captopril was given. The haemodynamic profile with chronic 
PRE-TREATMENT PLASMA NORADRENALINE $\mathrm{nmol} / \mathrm{I}$

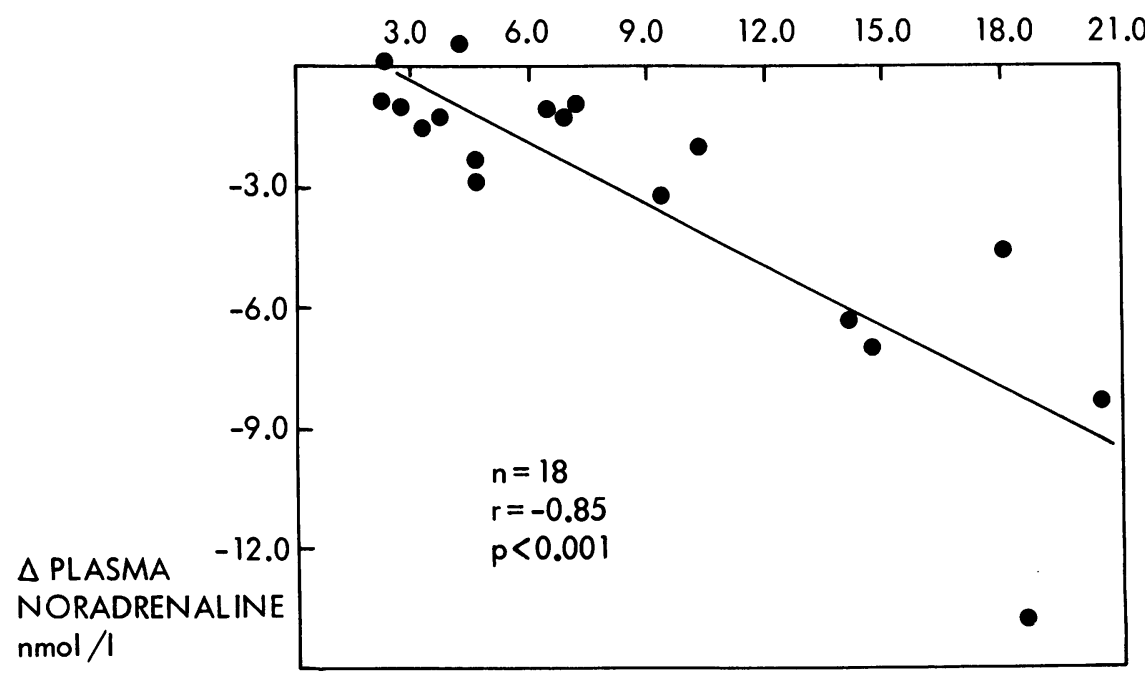

Fig. 5 Correlation of maximal decrease in plasma noradrenaline after captopril ( $50 \mathrm{mg}$ ) with the pretreatment level of noradrenaline.

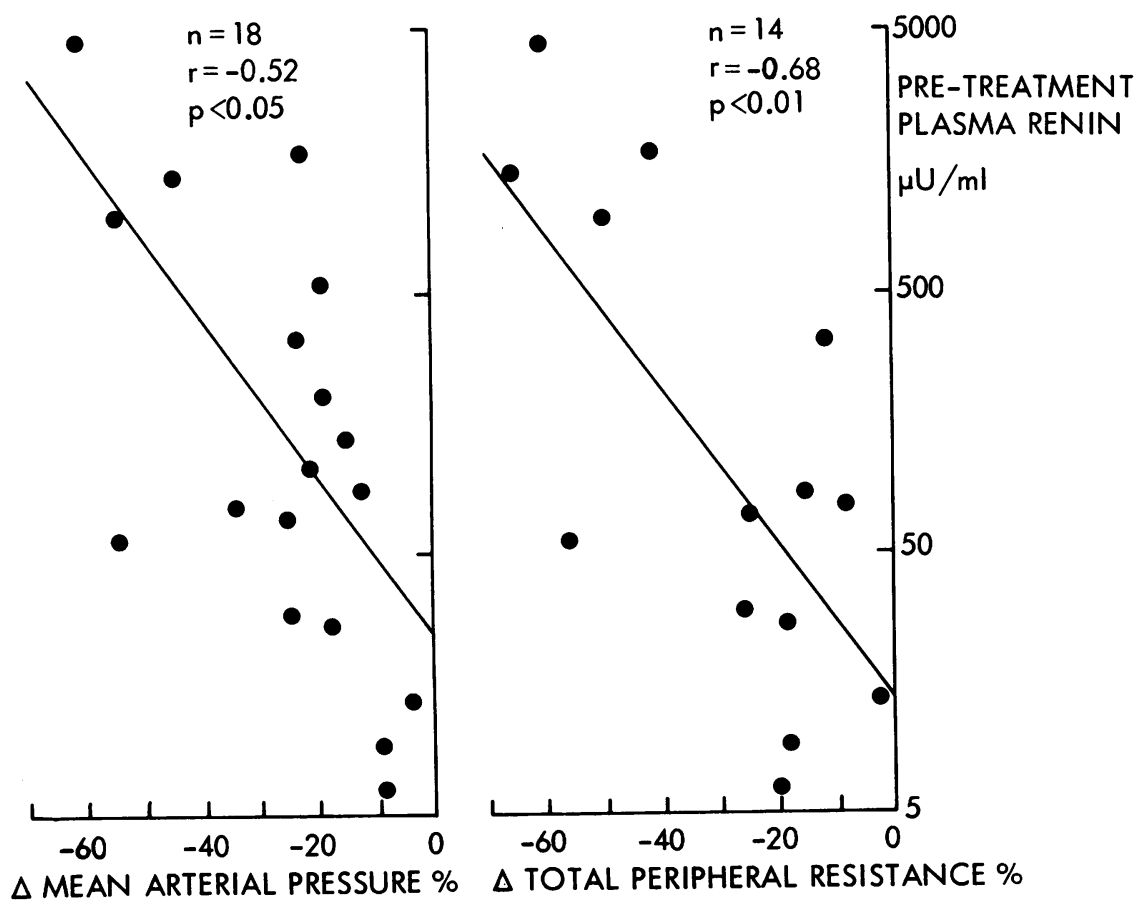

Fig. 6 Correlations between pretreatment plasma renin and the percentage changes of mean arterial pressure and total peripheral resistance 90 minutes after captopril (50 mg). 


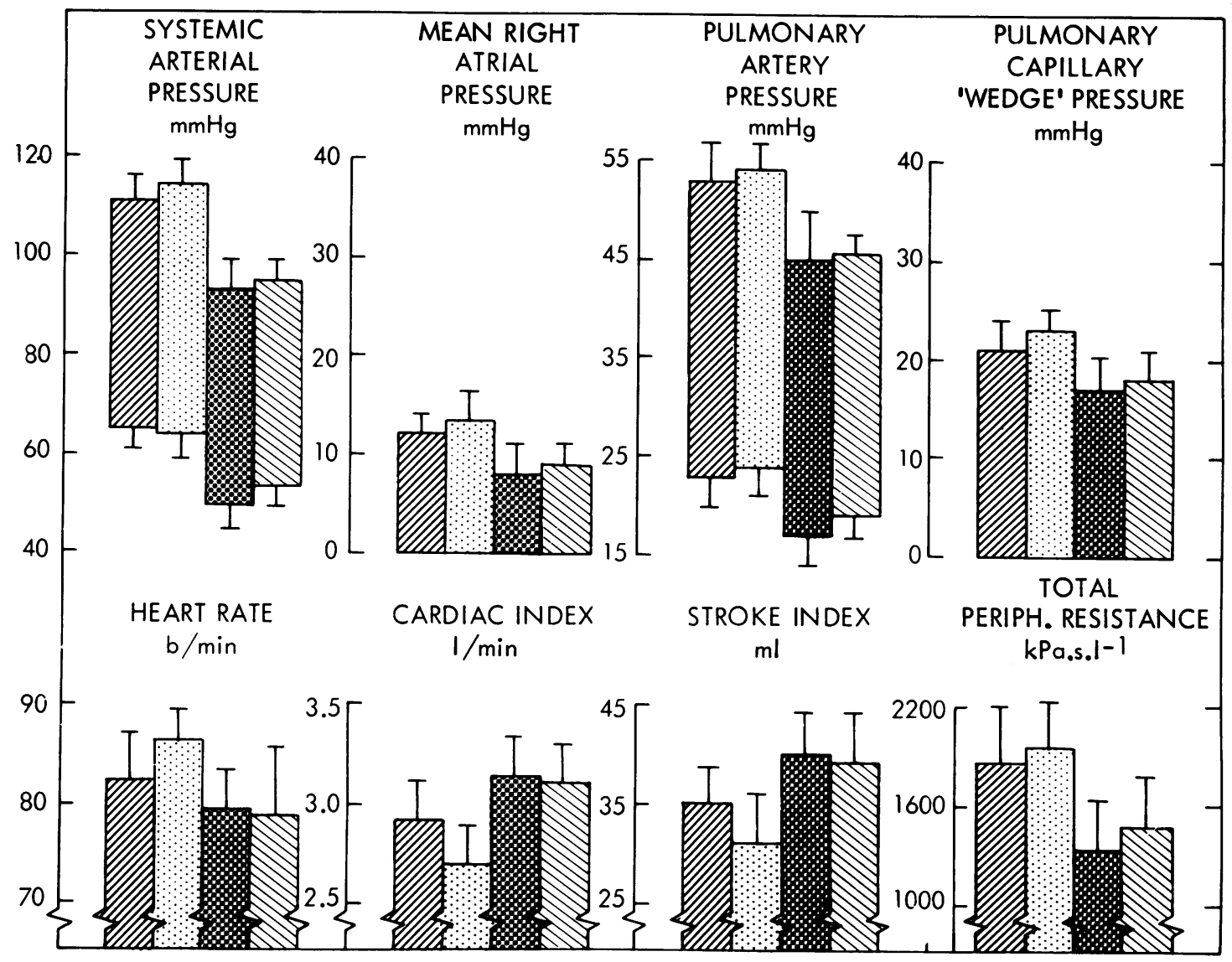

Fig. 7 Bargraphs representing haemodynamic variables measured during the different study phases in the nine patients (cases 9, 11-14, 16-19, see Table 2), who had captopril for three months.

measurements during the use of other vasodilatory drugs
measurements after cessation of these drugs for at least 24 hours
acute effects of captopril, $50 \mathrm{mg}$
long term effects of captopril

The acute effects of captopril in these nine patients were comparable with the responses in the whole group (Fig. 2 and .3). The acute effects of captopril were maintained during long-term treatment. When the haemodynamic effects of the previously used vasodilators were compared with long-term captopril significant differences were found for systemic arterial pressure (systolic and diastolic, $p<0.001$ ) and pulmonary arterial pressure (systolic and diastolic, $p<0 \cdot 01$ ).

captopril was not much different from that with previous vasodilating treatment but systemic arterial pressure was lower with chronic captopril. Though at first we did not intend to change the dose of the diuretics, it became clear from frequent determinations of serum potassium that the dose of the aldosterone antagonist, spironolactone, could be diminished and finally stopped in all patients. The doses of frusemide and digoxin were not altered. Before captopril serum potassium was $4 \cdot 0 \pm 0.2 \mathrm{mmol} / \mathrm{l}$ at a time when nearly all patients were taking spironolactone (Table 2). Evaluation at three months showed serum potassium was $4.4 \pm 0.3 \mathrm{mmol} / 1$, with no patient on spironolactone or oral potassium supplements. Serum creatinine rose from $120 \pm 11 \mu \mathrm{mol} / \mathrm{l}$ (range 96 to $175 \mu \mathrm{mol} / \mathrm{l}$ ) to $128 \pm 11 \mu \mathrm{mol} / \mathrm{l}$ (range 76 to $160 \mu \mathrm{mol} / \mathrm{l}$ ) after three months on captopril $(p<0.01)$. No significant change in body weight occurred during long-term captopril treatment; body weight was $70 \cdot 2 \pm 2.9 \mathrm{~kg}$ after three months as compared with $71 \cdot 6 \pm 2 \cdot 2 \mathrm{~kg}$ before 
Table 7 Correlations between captopril-induced haemodynamic changes ( 90 min) and pretreatment hormone levels

\begin{tabular}{|c|c|c|c|c|c|c|c|}
\hline \multirow{3}{*}{$\begin{array}{l}\text { Changes after captopril } \\
\text { (0-90 min) }\end{array}$} & \multirow[t]{3}{*}{ No. } & \multirow{2}{*}{\multicolumn{2}{|c|}{$\frac{\text { Versus }}{\text { Log plasma renin }}$}} & \multicolumn{4}{|c|}{ baseline values of } \\
\hline & & & & $\log p$ & osterone & $\log p$ & adrenaline \\
\hline & & $r$ & $p$ & $r$ & $p$ & $r$ & $p$ \\
\hline $\begin{array}{l}\text { Arterial pressure systolic } \downarrow \\
\text { diastolic } \downarrow \\
\text { mean } \downarrow \\
\text { Heart rate } \downarrow \\
\text { Cardiac index } \uparrow \\
\text { Cardiac work index - } \\
\text { Stroke index } \uparrow \\
\text { Stroke work index - } \\
\text { Mean right atrial pressure } \downarrow \\
\text { Mean pulmonary artery pressure } \downarrow \\
\text { Mean pulmonary capillary "wedge" pressure } \downarrow \\
\text { Total peripheral vascular resistance } \downarrow \\
\text { Pulmonary vascular resistance } \downarrow \\
\text { Plasma renin } \uparrow \\
\text { Plasma aldosterone } \downarrow \\
\text { Plasma noradrenaline } \downarrow\end{array}$ & $\begin{array}{l}18 \\
18 \\
14 \\
14 \\
18\end{array}$ & $\begin{array}{l}0.05 \\
0.62 \\
0.46 \\
0.58 \\
0.57 \\
0.06 \\
0.65 \\
0.03 \\
0.48 \\
0.47 \\
0.40 \\
0.71 \\
0.61 \\
0.80 \\
0.51 \\
0.59\end{array}$ & $\begin{array}{c}\text { NS } \\
<0.01 \\
<0.05 \\
<0.05 \\
<0.05 \\
\text { NS } \\
<0.05 \\
\text { NS } \\
<0.05 \\
<0.05 \\
<0.05 \\
<0.01 \\
<0.05 \\
<0.001 \\
<0.05 \\
<0.05\end{array}$ & $\begin{array}{l}0.27 \\
0.39 \\
0.21 \\
0.41 \\
0.58 \\
0.14 \\
0.71 \\
0.16 \\
0.18 \\
0.24 \\
0.11 \\
0.71 \\
0.60 \\
0.64 \\
0.82 \\
0.35\end{array}$ & $\begin{array}{c}\text { NS } \\
\text { NS } \\
<0.05 \\
\text { NS } \\
<0.01 \\
\text { NS } \\
\text { NS } \\
<0.01 \\
<0.05 \\
<0.01 \\
<0.001 \\
\text { NS }\end{array}$ & $\begin{array}{l}0.09 \\
0.34 \\
0.07 \\
0.63 \\
0.30 \\
0.24 \\
0.40 \\
0.35 \\
0.26 \\
0.26 \\
0.26 \\
0.51 \\
0.36 \\
0.61 \\
0.46 \\
0.77\end{array}$ & $\begin{array}{c}\text { NS } \\
<0.01 \\
\text { NS } \\
\text { NS } \\
\\
\text { NS } \\
<0.05 \\
\text { NS } \\
<0.01 \\
<0.05 \\
<0.001\end{array}$ \\
\hline
\end{tabular}

captopril. No patient developed skin rash, proteinuria, or leucopenia.

\section{Discussion}

It was remarkable how effective a single dose of captopril was in our patients whether or not they were in acute or chronic failure. As total peripheral resistance fell, the heart was relieved and stroke volume and cardiac output rose. Captopril also had a distinct effect on the preload of the heart as indicated by the decrease in cardiac filling pressures. Our study gives no detailed insight into the mechanism of this decrease. The fall in right atrial pressure has been reported to precede the fall in pulmonary arterial pressure and pulmonary capillary "wedge" pressure. ${ }^{8}$ This suggests that an effect of captopril on venous tone rather than an improvement of forward output of the heart is responsible for the observed decrease in cardiac filling pressures. In our study, however, the changes in filling pressures of the right and left side of the heart occurred synchronously.

Plasma renin is often high in heart failure but not invariably so. In our series it was increased in most patients with chronic heart failure who were on diuretics, whereas it was normal or even low in the patients with acute myocardial infarction who were not on diuretics. Thus, stimulation of the renin angiotensin system in normotensive heart failure might be a consequence of treatment rather than a consequence of the disease. This seems to contrast with sympathetic activity as reflected by plasma noradrenaline. High concentrations of noradrenaline were observed whether or not the patients had been on diuretics. The effect of captopril on peripheral resistance was positively correlated with pretreatment plasma renin, as were the effects on stroke volume, cardiac output, and cardiac filling pressures. The correlations, however, were weak, and the changes in the patients with normal or moderately raised renin were nearly as great as in those with grossly raised renin.

A notable feature of the cardiovascular actions of captopril is its apparent interference with baroreflex function. Heart rate did not rise in our patients despite a drop in systemic arterial pressure. This has also been reported by others. ${ }^{31} 32$ Attenuation of circulatory reflexes in congestive heart failure has been proposed as an underlying mechanism. ${ }^{3}$ Heart rate, however, is also not increased when arterial pressure is lowered by captopril in subjects with normal heart function. ${ }^{33}$ From experiments in dogs, Hatton et al..$^{34}$ concluded that captopril displaced the setpoint of the arterial baroreflex to a lower pressure without modifying the sensitivity of the reflex.

Ideally the decrease in vascular resistance after captopril should be balanced by an increase in cardiac output so that perfusion pressure of the different organs is maintained. Clearly this ideal was not met. Systemic arterial pressure fell, in some cases to an 을 alarmingly low level with the potential danger of a $\gg$ deleterious effect on coronary blood flow. On the other hand, the decrease in heart rate and the concomitant $N$ reductions in cardiac filling pressures and systemic arterial pressure and thereby in left vascular wall tension suggest that myocardial oxygen demand is diminished by captopril.

Of the 14 patients on long-term captopril, four died $\varrho$ within a month after initial clinical improvement. They had ischaemic heart disease. In congestive heart failure ? the cutaneous, splanchnic, and renal vascular beds are particularly prone to neurohumorally induced vasoconstriction. ${ }^{35}$ In this way, for instance during exercise, blood flow is shunted from the renal and $\stackrel{\unrhd}{\perp}$ splanchnic circulation to that of skeletal muscle, heart, 
and brain. It is therefore conceivable that in our patients who died suddenly captopril interfered with the normal redistribution of blood flow during exercise, which may have led to myocardial ischaemia.

The relatively high doses of captopril we have used may have contributed to the low systemic arterial pressure in our patients. Symptomatic hypotension, however, has also been observed with doses as low as $6.25 \mathrm{mg}$. 32 Our study does not give an indication of what the optimal dose of captopril should be, but recent experience in patients with heart failure and in patients with severe hypertension suggests that captopril in daily doses not higher than $75 \mathrm{mg}$ is effective when combined with a diuretic. ${ }^{32}{ }^{36}$ Such a regimen might reduce the incidence of side effects. The side effects that occur most frequently are skin rash, loss of taste, proteinuria, and leucopenia. These were not encountered in our small series of patients.

In conclusion, oral angiotensin-converting enzyme inhibition by captopril has a profound effect on cardiocirculatory control mechanisms, which are altered during heart failure. Heart rate, total peripheral resistance, cardiac filling pressures, and the increased plasma concentrations of aldosterone and noradrenaline are lowered while stroke volume is increased. In some patients the beneficial acute effects are maintained in the long run. During treatment of heart failure with high ceiling diuretics such as frusemide and ethacrynic acid in combination with captopril, potassium supplements or aldosterone antagonists are no longer needed. In the majority of our severe cases, combined treatment with frusemide and captopril resulted in a low systemic arterial pressure. This may compromise coronary circulation, particularly during exercise. Before captopril can be recommended as a useful drug for the treatment of heart failure, particularly in coronary artery disease, more insight into its effects on coronary blood flow is required.

We thank Dr P Pigott and Dr J Hill (Squibb) for providing the captopril tablets.

\section{References}

1 Chatterjee K, Parmley WW. The role of vasodilator therapy in heart failure. Progr Cardiovasc Dis 1977; 19: 301-25.

2 Symposium on vasodilator and inotropic therapy of heart failure. Mason DT, ed. Am F Med 1978; 65: 101-216.

3 Cohn JN, Franciosa JA. Vasodilator therapy of cardiac failure. N Englf Med 1977; 297: 27-31, 254-8.

4 Zelis R, Flaim SF, Moskowitz RM, Nellis SH. Editorial: How much can we expect from vasodilator therapy in congestive heart failure? Circulation 1979; 59: 1092-7.

5 Majid PA, Sharma B, Taylor SH. Phentolamine for vasodilator treatment of severe heart-failure. Lancet 1971; ii: 719-24.
6 Awan NA, Miller RR, Miller MP, Specht K, Vera Z, Mason DT. Clinical pharmacology and therapeutic application of prazosin in acute and chronic refractory congestive heart failure: balanced systemic venous and arterial dilation improving pulmonary congestion and cardiac output. Am f Med 1978; 65: 146-54.

7 Curtiss C, Cohn JN, Vrobel T, Franciosa JA. Role of the renin-angiotensin system in the systemic vasoconstriction of chronic congestive heart failure. Circulation 1978; 58: 763-70.

8 Turini GA, Brunner HR, Gribic M, Waeber B, Gavras H. Improvement of chronic congestive heart-failure by oral captopril. Lancet 1979; i: 1213-5.

9 Demoulin JC, Bertholet M, Soumagne D, David JL, Kulbertus HE. 5- $\mathrm{HT}_{2}$-receptor blockade in the treatment of heart failure. Lancet 1981 ; i: 1186-8.

10 Packer M, Meller J. Oral vasodilator therapy for chronic heart failure: a plea for caution. Editorial. Am 7 Cardiol 1978; 42: 686-9.

11 Panel discussion: vasodilators in the long-term treatment of heart failure, practical guidelines. In Rutishauser W, ed. The place of vasodilators in the long-term treatment of intractable heart failure. Bern: Hans Huber, 1981: 82-99.

12 Walsh WF, Greenberg BH. Results of long-term vasodilator therapy in patients with refractory congestive heart failure. Circulation 1981; 64: 499-505.

13 LeJemtel TH, Elkayan C, Ribner HS, et al. Variable hemodynamic response to oral hydralazine in patients with refractory congestive heart failure. Eur Heart f 1980; 1: 157-63.

14 Packer M, Meller J, Gorlin R, Herman MV. Hemodynamic and clinical tachyphylaxis to prazosin-mediated afterload reduction in severe chronic congestive heart failure. Circulation 1979; 59: 531-9.

15 Arnold SB, Williams RL, Ports TA, et al. Attenuation of prazosin effect on cardiac output in chronic heart failure. Ann Intern Med 1979; 91: 345-9.

16 Stein L, Henry DP, Weinberger MH. Increases in plasma norepinephrine during prazosin therapy for chronic congestive heart failure. Am F Med 1981; 70: 825-32.

17 Cody RJ Jr, Tarazi RC, Bravo EL, Fouad FM. Haemodynamics of orally-active converting enzyme inhibitor (SQ 14225) in hypertensive patients. Clin Sci Mol Med 1978; 55: 453-9.

18 Atlas SA, Case DB, Sealey JE, Laragh JH, McKinstry $\mathrm{DN}$. Interruption of the renin-angiotensin system in hypertensive patients by captopril induces sustained reduction in aldosterone secretion, potassium retention and natriuresis. Hypertension 1979; 1: 274-80.

19 DeBruyn JHB, Man in't Veld AJ, Wenting GJ, Derkx FHM, Schalekamp MADH. Haemodynamic profile of captopril treatment in various forms of hypertension. Eur f Clin Pharmacol 1981; 20: 163-8.

20 Tarazi RC, Fouad FM, Ceimo JK, Bravo EL. Renin, aldosterone and cardiac decompensation: studies with an oral converting enzyme inhibitor in heart failure. $A m \mathcal{F}$ Cardiol 1979; 44: 1013-8.

21 Faxon DP, Halperin JL, Creager MA, Gavras H, Schick EC, Ryan TJ. Angiotensin inhibition in severe heart failure: acute central and limb hemodynamic effects of captopril with observations on sustained oral therapy. Am Heart f 1981; 101: 548-56. 
22 Levine TB, Franciosa JA, Cohn JN. Acute and long-term response to an oral converting-enzyme inhibitor, captopril, in congestive heart failure. Circulation 1980; 62: $35-41$.

23 Maslowski AH, Ikram H, Nicholls MG, Espiner EA. Haemodynamic, hormonal, and electrolyte response to captopril in resistant heart failure. Lancet 1981; i: 71-4.

24 Brown JJ, Davies DL, Johnson VW, Lever AF, Robertson JIS. Renin relationships in congestive cardiac failure, treated and untreated. Am Heart f 1970; 80: 329_ 42.

25 Dzau VJ, Colucci WS, Hollenberg NK, Williams GH. Relation of the renin-angiotensin-aldosterone system to clinical state in congestive heart failure. Circulation 1981; 63: 645-51.

26 Ten Cate FJ, Hugenholtz PG, Roelandt J. Ultrasound study of dynamic behaviour of left ventricle in genetic asymmetric septal hypertrophy. $B r$ Heart $\mathcal{F} 1977$; 39: 627-33.

27 Derkx FHM, Gool JMG van, Wenting GJ, Verhoeven RP, Man in't Veld AJ, Schalekamp MADH. Inactive renin in human plasma. Lancet 1976; ii: 496-9.

28 Fraser R, Guest S, Young J. A comparison of doubleisotope derivative and radioimmunological estimation of plasma aldosterone concentration in man. Clin Sci Mol Med 1973; 45: 411-5.

29 Henry DP, Starman BJ, Johnson DG, Williams RH. A sensitive radio-enzymatic assay for norepinephrine in tissues and plasma. Life Sci 1975; 16: 375-84.

30 New York Heart Association Criteria Committee.
Nomenclature and criteria for diagnosis of diseases of the heart and great vessels. 7th ed. Boston: Little, Brown, 1973: 286.

31 Creager MA, Halperin JL, Bernard DB, et al. Acute regional circulatory and renal hemodynamic effects of converting-enzyme inhibition in patients with congestive heart failure. Circulation 1981; 64: 483-9.

32 Sharpe DN, Douglas JE, Coxon RJ, Long B. Low-dose captopril in chronic heart failure: acute haemodynamic effects and long-term treatment. Lancet 1980; ii: 1154-7.

33 MacGregor GA, Markandu ND, Roulson JE, Jones JC, Morton JJ. Maintenance of blood pressure by the reninangiotensin system in normal man. Nature 1981; 291: 329-31.

34 Hatton R, Clough D, Faulkner K, Conway J. Angiotensinconverting enzyme inhibitor resets baroreceptor reflexes in conscious dogs. Hypertension 1981; 3: 676-81.

35 Zelis R, ed. The peripheral circulations. New York: Grune and Stratton, 1975.

36 Veterans Administration Cooperative Study Group on antihypertensive agents. Captopril: evaluation of low doses, twice-daily doses, and the addition of diuretic for the treatment of mild to moderate hypertension. Clin $\mathrm{Sci}$ Mol Med 1982; 63: 443s-5s.

Requests for reprints to Professor M A D H Schalekamp, Department of Internal Medicine I, Room P 434, University Hospital Dijkzigt, Dr Molewaterplein 40, 3015 GD Rotterdam, The Netherlands. 